\title{
Remembering Rousseau
}

The year 2012 marks the tercentenary of the birth of Jean-Jacques Rousseau as well as the 250th anniversary of the publication of two of his major works, the Social Contract and the Emile. As part of the Rousseau 2012/Dignity project at the University of Notre Dame, we hope this special issue will contribute to an international effort to revive and reassess the thought and legacy of the eighteenth-century political philosopher.

In "The Critical Function of Genealogy in the Thought of J.-J. Rousseau" Frederick Neuhouser lays out some of the fundamental principles of Rousseau's moral and political philosophy. In his Discourse on the Origin and Foundations of Inequality among Men, Rousseau first attempts to discover whether those foundations inhere in human nature by abstracting from the characteristics human beings acquire only by associating with others. He finds that by nature human beings are attached to their own well-being or preservation, pity the suffering of other sentient beings, possess a host of latent cognitive faculties that enable them to acquire language, thought, and the arts and a primitive form of free will that allows them to follow or resist their immediate impulses. Rousseau is thus able not only to establish a standard of right - the happiness and freedom human beings possess by nature; he is also able to locate the source of the pernicious forms of inequality that develop in and with human society in the concern individuals acquire for their relative standing in the eyes of others. Having discovered that the origins of moral and political (as opposed to physical and intellectual) inequality are not natural, Rousseau is also able to propose a possible remedy in the reciprocal recognition of the equality of citizens.

In "The Music of Reason in Rousseau's Essay on the Origin of Languages" Michael Davis pursues Rousseau's analysis of the origins of human rationality and political society even further. In his Essay on the Origin of Languages as in his Discourse on the Origin and the Foundations of Inequality among Men, Rousseau shows that the origin of political society is inseparable from the origin of language, which, in turn, is inseparable from the origin of reason. And toward the end of the Essay he argues that language has its origin in music. In emphasizing the priority of melody to harmony in music, the Essay on the Origin of Languages articulates the necessarily melodic, and hence temporal, character of human thought that forces him to present logical relations as if they were historical.

Christopher Bertram then examines "Rousseau's Legacy in Two Conceptions of the General Will." Some argue that Rousseau's definition of a legitimate government as "a form of association that will defend and 
protect the person and goods of each associate with the full common force, and by means of which each, united with all, nevertheless obeys only himself and remains as free as before" (SC I.6) can be satisfied only by a radical democracy in which all citizens actively participate. Because Rousseau distinguishes the will of any given people, which may merely represent their perceived self-interest, from "the general will," which cannot err, others argue that the "general will" constitutes a formal standard by which the legitimacy of particular expressions of the popular will should be measured. Bertram shows that both conceptions have textual support, and suggests that they can even be reconciled in Rousseau's own thought. They have nevertheless given rise to very different ideological legacies.

Using Rousseau's draft of a Plan for a Constitution for Corsica as a concrete example, in "Attending to Time and Place in Rousseau's Legislative Art" Denise Schaeffer investigates the way in which he thought the potential tension between what a sovereign people erroneously believes is good and the general will that is always right, but may not be guided by enlightened judgment, could be overcome. A wise legislator must not only be able to transform each individual, "who is by himself a perfect and solitary whole, into a part of a larger whole" (SC II.7). He must also know how to produce this collective ethos within a particular political context. And, Rousseau lets his readers see, because circumstances and people are always changing, there is an ongoing need for such knowledge.

As Rousseau's political writings show, he was particularly interested in determining what was always at least potentially true of human beings and what could be changed, either improved or corrupted. Like Plato's Socrates, to whom he often refers, Rousseau saw that such an investigation (or search for "self-knowledge") required an examination of extraordinary individuals and the ways in which they differed from others as well as the commonalities of the human species. Rousseau thus made himself, his life, his activities, and his thoughts the subject of many of his studies. The last three articles in this issue thus pursue the ambiguities and results of Rousseau's having made himself both the object and the narrator of the Emile, the Confessions, and the Reveries.

In "Do You See What I See?" John Scott uses two varieties of "reader response" theory to show how in the Emile Rousseau seeks to educate his readers. By describing the effects of the education a tutor named JeanJacques Rousseau has on a boy named Emile, Rousseau seeks gradually to change the way in which the reader understands, first, the nature of a child, and, ultimately, himself. In the Emile Rousseau does not propose a program for the education of others so much as he provides a demonstration of the way people can be made to see not only "things" but also themselves differently.

According to Laurence Cooper's "Nearer My True Self to Thee" and Victor Gourevitch's "A Provisional Reading of Rousseau's Reveries of the Solitary Walker," in the Confessions and the Reveries Rousseau relates his own return 
to nature from civilization on the basis of an exceptionally high degree of civilization. But, as Gourevitch emphasizes, the way back from civilization to nature is not the same as the path by which Rousseau suggests that human beings originally became civilized in his Discourse on the Origin of Inequality. Nor is it clear that many-or any-other human beings can acquire, much less maintain, the godlike contentment Rousseau achieves in and through an enforced solitude in which he finally perceives his own sentient existence to extend and encompass everything else. Is nature-or, more precisely, Rousseau's own nature-truly and unambiguously good?

Cooper presents Rousseau's recapturing of the goodness of his own nature in the Confessions as a spiritual journey that concludes with an understanding of the relation between man and God very different from the one articulated as the necessary basis for human morality in the creed of the Savoyard Vicar. Gourevitch emphasizes the temporal as well as the substantive complexities of Rousseau's narration of his "reveries." Although Rousseau claims that his "enemies" benefited him by expelling him from all human society and so forcing him to turn back to and into himself, he appears to contradict his claim to have freed himself entirely from any concern about their opinions of him (or his immortal fame) by writing down his meditations (even though he also claims to be writing only for himself). He clearly intends to present himself first as a victim and then to purge his readers of any pity they may feel for him by showing how he overcame his adversities. Rousseau relates the way in which he acquired something like the set of religious beliefs he attributes to the Savoyard Vicar, but then admits that they are subject to "insoluble objections." He concludes that it is necessary to communicate only useful truths, and so provokes the reader to ask how truthful or complete Rousseau's account of his own reveries is. The happiness he associates with his recapturing the sweet self-sufficiency of the sentiment of his existence on St. Peter's Island is admittedly transitory. Although he has experienced the pleasure of freely doing good to others, he has relinquished it, because he recognizes that the pleasure soon evaporates when benefiting others becomes a duty. His life is emphatically not that of a citizen. He suggests that his contemporaries have expelled him from their midst, because his living as free as possible from having to do what he does not want to do is a constant reproach to them. His thoughts, like his existence, are idle, which is to say, useless. He seeks to find nature free from artifice or convention. He is, however, clearly using language in writing down his reveries, the pleasures of which seem to exist primarily in his recollection of earlier experiences. It is not clear that he does or can succeed in his quest.

As Neuhouser, Bertram, and Cooper all point out, some of Rousseau's influence on later political thinkers and actors can be traced to the ambiguities characteristic of his thought. Because Rousseau appeared to say contradictory things, readers felt free to take what they liked and to ignore what they did not. As all the articles included in this issue explicitly seek to demonstrate, however, the depth and the richness of Rousseau's thought become evident 
only to those who seek to understand his reasons for maintaining both sides of the seeming ambiguities and paradoxes.

-Catherine H. Zuckert Editor 